\title{
Seasonal variation in nitrification and nitrate- reduction pathways in coastal sediments in the Gulf of Finland, Baltic Sea
}

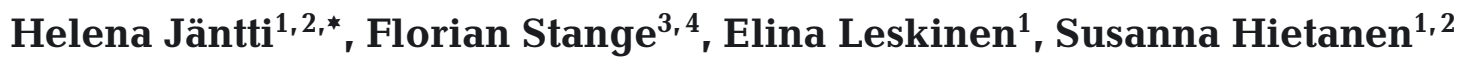 \\ ${ }^{1}$ Department of Environmental Sciences, Division of Aquatic Sciences, 00014 University of Helsinki, Finland \\ ${ }^{2}$ Tvärminne Zoological Station, University of Helsinki, 10900 Hanko, Finland \\ ${ }^{3}$ Helmholtz Centre for Environmental Research - UFZ, Department Soil Physics, 06120 Halle/Saale, Germany \\ ${ }^{4}$ Present address: Federal Institute for Geosciences and Natural Resources, 30655 Hannover, Germany
}

\begin{abstract}
The Baltic Sea is one of the most eutrophic marine areas in the world. The role of nitrogen as a eutrophicating nutrient in the Baltic Sea has remained controversial owing to a lack of understanding of nitrogen cycling in the area. We investigated the seasonal variation in sediment nitrification, denitrification, anaerobic ammonium oxidation (anammox), and dissimilatory nitrate reduction to ammonium (DNRA) at 2 coastal sites in the Gulf of Finland. In addition to the estimation of in situ rates, we assessed the potential for nitrification and denitrification in different seasons. The nitrification and nitrogen removal processes were maximal during the warm summer months, when the sediment organic content was highest. In colder seasons, the rates of nitrification and nitrate reduction measured under in situ conditions decreased, but the potential for nitrification remained equal to, or higher than, that during the warm months. The rates of denitrification and nitrification were usually higher in the accumulation basin, where the organic content of the sediment was higher, but the transportation area, despite lower denitrification rates and potential, typically had a higher potential for nitrification than the accumulation basin. Anammox and DNRA were not important nitrate sinks in any of the seasons sampled. The results also show that the rates of denitrification in the coastal Gulf of Finland sediment have decreased, and that benthic denitrification might be a less important sink for fixed nitrogen than previously assumed.
\end{abstract}

KEY WORDS: Sediment · Nitrification · Denitrification · Anammox · DNRA · Baltic Sea $\cdot$ Gulf of Finland Resale or republication not permitted without written consent of the publisher

\section{INTRODUCTION}

Anthropogenic eutrophication of the Baltic Sea is of great concern. Of the Baltic Sea sub-basins, the Gulf of Finland is the most eutrophicated and has been suffering from severe cyanobacterial blooms caused by excessive nutrient loading (Pitkänen \& Tamminen 1995). Nitrogen loading in particular is difficult to control, and the total nitrogen (TN) load per area in the Gulf of Finland is the highest in the entire Baltic Sea (HELCOM 2009). Nitrogen is removed from aquatic systems by microbially mediated anaerobic ammonium oxidation (anammox) and denitrification processes that convert the available forms of fixed nitrogen to dinitrogen gas $\left(\mathrm{N}_{2}\right)$. Coastal sediments are important sites for denitrification and often control the degree of eutrophication by acting as natural nitrogenremoval filters (Voss et al. 2005, Seitzinger et al. 2006). In previous measurements it was estimated that benthic denitrification in the Gulf of Finland is an important sink for fixed nitrogen (Tuominen et al. 1998, Hietanen \& Kuparinen 2008), but the controlling factors for denitrification have remained poorly understood. Before fixed nitrogen can be removed by denitrification or anammox, it must be converted to nitrite $\left(\mathrm{NO}_{2}^{-}\right)$or nitrate $\left(\mathrm{NO}_{3}{ }^{-}\right)$by the nitrification process. In nitrification, ammonium $\left(\mathrm{NH}_{4}{ }^{+}\right)$is oxidized to $\mathrm{NO}_{2}{ }^{-}$by ammonia-oxidizing bacteria (AOB), or by the recently discovered ammonia-oxidizing archaea (AOA; Könneke et al. 2005), and thereafter to $\mathrm{NO}_{3}^{-}$by nitrite- 
oxidizing bacteria (NOB). Nitrification is often one of the most important factors controlling the rates of nitrogen removal.

Sediments are important sites for nitrogen cycling because the sharp gradient of $\mathrm{O}_{2}$ in the sediment allows oxic nitrification and anoxic denitrification and anammox to operate in close proximity (Jenkins \& Kemp 1984, Jensen et al. 1993, 1994). Anoxic conditions, which commonly prevail at the sediment surface in the Gulf of Finland (HELCOM 2009), decrease nitrogen removal by closing down the coupled nitrification-denitrification pathway, which is the most important pathway for nitrogen removal (Tuominen et al. 1998, Hietanen \& Kuparinen 2008). When the sulfide oxidation rates and/or organic loading are high, and the concentrations of $\mathrm{O}_{2}$ and $\mathrm{NO}_{3}{ }^{-}$are low, dissimilatory nitrate reduction to ammonium (DNRA) can become an important pathway for nitrate reduction (Tiedje et al. 1982, Rysgaard et al. 1996, Christensen et al. 2000, Burgin \& Hamilton 2007). In terms of eutrophication, DNRA is a harmful process because it maintains nitrogen in a bioavailable form. Karlsson et al. (2005) studied laminated Baltic Sea sediment and observed $\mathrm{NO}_{3}{ }^{-}$-consumption in the sediment that could not be explained by denitrification, suggesting that DNRA could be an important nitrate-reduction pathway enhancing the vicious cycle of eutrophication in the Baltic Sea.

To expand our understanding of nitrogen cycling in the Gulf of Finland, we investigated the seasonal variability in nitrification, nitrification potentials, and the $\mathrm{NO}_{3}{ }^{-}$-reduction pathways in the coastal Gulf of Finland accumulation basin and shallow transportation area.

\section{MATERIALS AND METHODS}

Study area. Two coastal stations in the northwestern Gulf of Finland, Storfjärden (59 51.31'N, $23^{\circ} 18.81^{\prime} \mathrm{E}$ ) and Muncken (59 $\left.51.14^{\prime} \mathrm{N}, 23^{\circ} 14.70^{\prime} \mathrm{E}\right)$, were sampled for sediment nitrification and nitratereduction pathways in September 2007 (only Storfjärden), April, August, and November 2008, and April,
August, and December 2009. Storfjärden represents a typical outer archipelago accumulation basin (Niemi 1975) in which the sediment is soft mud. It is $33 \mathrm{~m}$ in depth and is typically thermally stratified from June to September. The highest temperatures in the bottom water are measured in late autumn, when the thermal stratification breaks, and lowest in early spring, after the break-up of ice. Muncken is located $\sim 1 \mathrm{~km}$ from Storfjärden and is closer to the river outflow from Pojo Bay. It is a shallow $(11 \mathrm{~m})$ transportation area where the sediment is soft mud mixed with a small proportion of fine-grained sand. The highest sedimentation rates in the area occur in May after the spring bloom, when $\sim 80 \%$ of the sedimenting carbon reaches the bottom (Tallberg \& Heiskanen 1998).

Sampling and incubation. The temperature and salinity were recorded using a CTD probe (SIS CTD plus 100). The sediment was collected in acrylic cores, using a Gemini ( $\square 80 \mathrm{~mm}$, height $80 \mathrm{~cm}$ ) or Gemax ( $\square 90 \mathrm{~mm}$, height $80 \mathrm{~cm}$ ) twin corer with sediment and water in each core. The concentrations of $\mathrm{O}_{2}, \mathrm{NO}_{3}{ }^{-}$and $\mathrm{NH}_{4}{ }^{+}$in the bottom water were measured by withdrawing a water sample from $\sim 5 \mathrm{~cm}$ above the sediment surface in a core. The sediment's organic content (as a loss on ignition, LOI, in \%) and porosity were determined from the topmost $1 \mathrm{~cm}$ of the sediment. Each large core was sub-sampled into 3 or 4 smaller acrylic plastic cores $(\square 26 \mathrm{~mm}$, height $20 \mathrm{~cm}$ ), so that there was $\sim 5 \mathrm{~cm}$ of sediment and $13 \mathrm{~cm}$ of water in each sub-sample. The remaining volume in the core was filled by caps, leaving no air in the cores. The subsamples were transported in cooler boxes to the shore within $2 \mathrm{~h}$ for further treatments.

The intact sediment cores for measuring denitrification, anammox and DNRA were enriched with potassium nitrate $\left(\mathrm{K}^{15} \mathrm{NO}_{3}{ }^{-}, 99 \%{ }^{15} \mathrm{~N}\right)$ to final concentrations of $40,80,120$ and $160 \mu \mathrm{M}^{15} \mathrm{NO}_{3}{ }^{-}$in the overlying water ( $\mathrm{n}=4$ per concentration; Table 1).

The intact sediment cores for measuring nitrification were enriched with ammonium chloride $\left({ }^{15} \mathrm{NH}_{4} \mathrm{Cl}\right.$, $\left.99 \%{ }^{15} \mathrm{~N}\right)$ to final concentrations of $100 \mu \mathrm{M}, 200$ and $300 \mu \mathrm{M}^{15} \mathrm{NH}_{4}{ }^{+}(\mathrm{n}=4$ per concentration; Table 1$)$.

Table 1. Experimental set-up. $D_{\mathrm{w}}=$ denitrification based on $\mathrm{NO}_{3}{ }^{-}$from the overlying water; $D_{\mathrm{n}}=$ denitrification coupled to nitrification; anammox = anaerobic ammonium oxidation; $N_{\mathrm{w}}=$ nitrification producing $\mathrm{NO}_{3}{ }^{-}$to the water column; ${ }^{15} \mathrm{~N}_{2}=$ potential coupled nitrification-denitrification; DNRA = dissimilatory nitrate reduction to ammonium; IPT $=$ isotope-pairing technique; $r$-IPT $=$ revised isotope-pairing technique; IRMS = isotope ratio mass spectrometry; SPINMAS = an automated sample preparation unit for inorganic nitrogen species coupled to a quadrupole mass spectrometer

\begin{tabular}{|llll|}
\hline Processes measured & $D_{\mathrm{w}}, D_{\mathrm{n}}$, anammox & $N_{\mathrm{w},}{ }^{15} \mathrm{~N}_{2}$ & DNRA \\
\hline Method & $\mathrm{IPT}, \mathrm{r}$-IPT & ${ }^{15} \mathrm{NH}_{4}^{+}$oxidation & ${ }^{15} \mathrm{NO}_{3}{ }^{-}$reduction to ${ }^{15} \mathrm{NH}_{4}{ }^{+}$ \\
Substrate tracer added & ${ }^{15} \mathrm{NO}_{3}^{-}$ & ${ }^{15} \mathrm{NH}_{4}^{+}$ & ${ }^{15} \mathrm{NO}_{3}^{-}{ }^{-}$ \\
Products measured & ${ }^{29} \mathrm{~N}_{2}{ }^{30} \mathrm{~N}_{2}$ & ${ }^{15} \mathrm{NO}_{3}{ }^{-},{ }^{29} \mathrm{~N}_{2} \&{ }^{30} \mathrm{~N}_{2}$ & ${ }^{15} \mathrm{NH}_{4}^{+}$ \\
Analysis methods & IRMS & SPINMAS, IRMS & $\mathrm{NH}_{3}$ diffusion combined with IRMS \\
\hline
\end{tabular}


All cores were incubated for $4 \mathrm{~h}$ at the in situ temperature with mixing provided by magnetic stirring bars in the caps. After incubation, the sediment was mixed with the overlying water and the cores were submerged in ice-cold water and allowed to settle for $\sim 3 \mathrm{~min}$. A water sample (12 $\mathrm{ml}$ ) for isotopic analysis of $\mathrm{N}_{2}$ was withdrawn from the top of the core into a gastight glass vial (Exetainer, Labco Scientific) containing $0.5 \mathrm{ml}$ zinc chloride $\left(\mathrm{ZnCl}_{2}\right)(100 \% \mathrm{w} / \mathrm{v})$. The $\mathrm{N}_{2}$ samples from September 2007 were analyzed at Iso-Analytical Laboratories in Crewe, Cheshire, UK, and the samples from 2008 and 2009 were analyzed at the National Environmental Research Institute (NERI), University of Aarhus, Silkeborg, Denmark. The remainder of the core content was centrifuged $(237 \times g$, $10 \mathrm{~min}$ ) and the supernatant was filtered (pre-washed $0.2 \mu \mathrm{m}$ syringe filter, Acrodisc) and frozen immediately at $-20^{\circ} \mathrm{C}$ for ${ }^{15} \mathrm{NH}_{4}{ }^{+}$analysis (DNRA samples) and ${ }^{15} \mathrm{NO}_{3}{ }^{-}$analysis (nitrification samples). If mussels (Macoma balthica) or mussel shells were present (observed on average in 1 or 2 cores per sampling), the cores were marked and discarded from the calculations if the rates deviated substantially from those of the other cores. However, this had to be done very rarely. DNRA and ${ }^{15} \mathrm{NO}_{3}{ }^{-}$production were not measured in April 2009 (Muncken only) or December 2009 (both stations).

${ }^{15} \mathrm{NH}_{4}{ }^{+}$analysis. ${ }^{15} \mathrm{NH}_{4}{ }^{+}$analysis from the September 2007 samples was done in NERI, using a combined microdiffusion-hypobromite oxidation method (Risgaard-Petersen et al. 1995). For the remaining samples, the ${ }^{15} \mathrm{NH}_{4}{ }^{+}$analysis was modified from the ${ }^{15} \mathrm{NO}_{3}{ }^{-}$ analysis presented in Sigman et al. (1997) by excluding the dissolved organic nitrogen (DON) and $\mathrm{NH}_{4}{ }^{+}$ removals, and the conversion of $\mathrm{NO}_{3}{ }^{-}$to $\mathrm{NH}_{4}{ }^{+}$. The concentration of $\mathrm{NH}_{4}{ }^{+}$in the samples was determined using the method of Solorzano (1969) to ensure an optimal amount of $\mathrm{NH}_{4}{ }^{+}$(1 to $7 \mu \mathrm{mol} \mathrm{N}$ ) for the extraction. The samples were then placed in $100 \mathrm{ml}$ bottles; salinity was adjusted to 30 with sodium chloride ( $\mathrm{NaCl}), 1 \mathrm{~g}$ of magnesium oxide (MgO) was added to each $100 \mathrm{ml}$ of sample, and the $\mathrm{pH}$ was set at 11 with $10 \%$ sodium hydroxide $(\mathrm{NaOH})$. The $\mathrm{NH}_{4}{ }^{+}$was extracted in diffusion packets ( 90\% $\mathrm{NH}_{4}^{+}$recovery) that were constructed by packing an acidified (30 $\mu \mathrm{l} 4 \mathrm{~N}$ phosphoric acid $\left(\mathrm{H}_{3} \mathrm{PO}_{4}\right)$ ) fiberglass filter (Whatman, GF/D, $\square 5$ $\mathrm{mm}$ ), between membrane filters (Millipore LCWP 02500). After increasing the $\mathrm{pH}$, and the addition of the diffusion pack, the bottles were immediately closed and sealed with Parafilm ${ }^{\circledR}$ and polytetrafluoroethylene (PTFE)-coated screw caps. The bottles were incubated upside down for $14 \mathrm{~d}$ at room temperature on a shaker table (150 rpm). Thereafter, the diffusion packets were removed from the bottles, rinsed with $10 \%$ hydrochloric acid ( $\mathrm{HCl}$ ) and MilliQ-water, and placed on a desic- cator to dry. After $2 \mathrm{~d}$ of drying, the packets were disassembled and the fiberglass filters were packed into silver foil cups (Elemental Microanalyses). The isotopic ratio of the extracted nitrogen was analyzed in IsoAnalytical Laboratories.

${ }^{15} \mathrm{NO}_{3}{ }^{-}$analysis. The ${ }^{15} \mathrm{NO}_{3}{ }^{-}$analysis was done by using the SPINMAS (an automated sample preparation unit for inorganic nitrogen species coupled to a quadrupole mass spectrometer) method. The protocol followed Stange et al. (2007), and the measurements were done in 2 replicates at the Helmholtz Centre for Environmental Research in Halle/Saale, Germany. Approximately $1 \mathrm{ml}$ of sample was mixed in a reaction vial (22 ml, capped with a $2 \mathrm{~mm}$ septum) with $3 \mathrm{ml}$ of acidic vanadium chloride $\left(\mathrm{V}[\mathrm{III}] \mathrm{Cl}_{3}\right)$ solution (15.7 $\mathrm{g}$ $\mathrm{VCl}_{3}$ and $160 \mathrm{ml} 32 \% \mathrm{HCl}$ in $1000 \mathrm{ml}$ ) at $85^{\circ} \mathrm{C}$ for $1 \mathrm{~min}$ to form nitric oxide (NO). The NO produced was transported with helium as a carrier gas $\left(10 \mathrm{ml} \mathrm{min}^{-1}\right)$ to the inlet capillary (open split) of a quadrupole mass spectrometer (GAM 400, InProcess Instruments), in which the ${ }^{15} \mathrm{~N}$ abundance of the $\mathrm{NO}$ was analyzed. $\mathrm{H}_{2} \mathrm{O}$ and $\mathrm{CO}_{2}$ were removed prior to the ${ }^{15} \mathrm{~N}$ analysis with a cryotrap $\left(-120^{\circ} \mathrm{C}\right)$.

Calculations and statistical analyses. Because processes were measured by adding excess substrate, the process rates had to be extrapolated for in situ conditions, and represent estimates of process rates under in situ conditions. The total sediment nitrification rate includes the nitrification providing $\mathrm{NO}_{3}{ }^{-}$to the water column $\left(N_{\mathrm{w}}{ }^{15} \mathrm{NH}_{4}{ }^{+}\right.$oxidation samples) and the nitrification coupled to denitrification ( $D_{\mathrm{n}}$ i isotope-pairing technique [IPT], see below). $D_{\mathrm{n}}$ was used as an estimate of coupled nitrification-denitrification instead of ${ }^{15} \mathrm{~N}_{2}\left({ }^{29} \mathrm{~N}_{2}+2 \times{ }^{30} \mathrm{~N}_{2}\right)$ production from the ${ }^{15} \mathrm{NH}_{4}{ }^{+}$oxidation samples because the IPT was less prone to biases caused by substrate limitation. $N_{\mathrm{w}}$ was calculated by plotting the ${ }^{15} \mathrm{NO}_{3}{ }^{-}$production from ${ }^{15} \mathrm{NH}_{4}{ }^{+}$oxidation samples against the total $\mathrm{NH}_{4}{ }^{+}$concentration and extrapolating linearly the $\mathrm{NO}_{3}{ }^{-}$production to the ambient $\mathrm{NH}_{4}{ }^{+}$level. If no linear significant correlation was found, $N_{\mathrm{w}}$ was the average of ${ }^{15} \mathrm{NO}_{3}{ }^{-}$productions. The denitrification rate was calculated using the IPT (Nielsen 1992). The total nitrate-reduction rates were calculated by combining denitrification based on $\mathrm{NO}_{3}{ }^{-}$ from nitrification $\left(D_{\mathrm{n}}\right.$ IPT), denitrification based on $\mathrm{NO}_{3}{ }^{-}$in the sediment-overlying water ( $D_{\text {wi }}$ IPT), and the DNRA rate (Dong et al. 2009). The traditional IPT is not a reliable denitrification measurement technique if anammox is present. Anammox produces ${ }^{29} \mathrm{~N}_{2}$ by combining the added ${ }^{15} \mathrm{NO}_{3}{ }^{-}$and ambient ${ }^{14} \mathrm{NH}_{4}{ }^{+}$. This violates the binomial distribution of ${ }^{28} \mathrm{~N}_{2},{ }^{29} \mathrm{~N}_{2}$ and ${ }^{30} \mathrm{~N}_{2}$ productions, which is the fundamental assumption of IPT. When anammox was detected (November 2008 and December 2009), denitrification and anammox were calculated according to the revised IPT (r-IPT; 
Risgaard-Petersen et al. 2003, 2004). The results of the IPT data are also unreliable when denitrification is not nitrate-limited (Nielsen 1992, Steingruber et al. 2001). On these occasions (Muncken, April 2008 and 2009; Storfjärden, April 2009) denitrification coupled to nitrification was calculated from nitrification samples, in which we assumed that the $\mathrm{NO}_{3}{ }^{-}$produced by nitrification diffused at similar ${ }^{15 / 14} \mathrm{~N}$ ratios to the bottom water and to the denitrification layer so that coupled nitrification-denitrification could be expressed as:

$$
\text { Coupled nitrification }- \text { denitrification }=\frac{N_{\mathrm{d}}}{r}
$$

where $r$ is the ${ }^{15 / 14} \mathrm{~N}$ ratio of the $\mathrm{NO}_{3}{ }^{-}$effluxing from the sediment (Jäntti et al. unpubl.). By using this method, the assessment of $D_{\mathrm{w}}$ is not possible, and consequently $D_{\mathrm{w}}$ data are not available when this method was applied. The nitrification potential was assessed from the nitrification samples by combining the production of ${ }^{15} \mathrm{NO}_{3}{ }^{-}$and ${ }^{15} \mathrm{~N}_{2}$ at the given ${ }^{15} \mathrm{NH}_{4}{ }^{+}$concentration, assuming that the added ${ }^{15} \mathrm{NH}_{4}{ }^{+}$was the only substrate for nitrification. This assumption was made because the concentration of ${ }^{15} \mathrm{NH}_{4}{ }^{+}$added was at least 20 -fold higher than the ambient $\mathrm{NH}_{4}{ }^{+}$concentration in the water. Statistical analyses were done with the SPSS statistical package. Correlations between the environmental variables and the process rates were done by using the non-parametric Spearman correlation coefficient $\left(\mathrm{r}_{\mathrm{S}}\right)$ analysis and were defined as significant when $\mathrm{p}<0.05$.

\section{RESULTS}

The physical and chemical environmental characteristics in the bottom water followed a seasonal cycle at both stations. High temperatures in August cooccurred with maximum $\mathrm{NH}_{4}^{+}$concentration and LOI\% as well as the year's lowest $\mathrm{O}_{2}$ and $\mathrm{NO}_{3}{ }^{-}$concentrations. When the temperatures began to decrease, the $\mathrm{LOI} \%$ and $\mathrm{NH}_{4}{ }^{+}$concentrations decreased and both $\mathrm{NO}_{3}{ }^{-}$and $\mathrm{O}_{2}$ concentrations increased. With the exception of December 2009, the LOI\% was always higher at Storfjärden than at Muncken (Table 2). Two exceptional environmental variations occurred during the sampling period: the period January-April 2008 was unusually warm and no ice cover formed in the Gulf of Finland, and in December 2009, an upwelling event on the day before sampling increased the bottom water salinity from 6.4 to 7.0 , and decreased the temperature of the bottom water from 7.0 to $6.3^{\circ} \mathrm{C}$ at Storfjärden.

In spring, nitrification and denitrification typically showed low rates that nearly doubled in late summer and again decreased during the winter (Figs. 1 \& 2). An exception to this pattern was observed in Storfjärden
Table 2. Physical and chemical characteristics in the bottom water and sediment surface

\begin{tabular}{|lrrrrrr|}
\hline & $\begin{array}{r}\text { Temp } \\
\left({ }^{\circ} \mathrm{C}\right)\end{array}$ & Salinity & $\begin{array}{c}\mathrm{O}_{2} \\
\left(\mathrm{mg} \mathrm{l}^{-1}\right)\end{array}$ & $\begin{array}{r}\mathrm{NH}_{4}{ }^{+} \\
(\mu \mathrm{M})\end{array}$ & $\begin{array}{c}\mathrm{NO}_{3}{ }^{-} \\
(\mu \mathrm{M})\end{array}$ & $\begin{array}{r}\text { LOI } \\
(\%)\end{array}$ \\
\hline Storfjärden & & & & & & \\
Sept 07 & 8.9 & 6.3 & 5.3 & 4.5 & 2.8 & 22.0 \\
Apr 08 & 2.4 & 5.4 & 13.2 & 2.5 & 2.6 & 17.7 \\
Aug 08 & 16.2 & 5.9 & 6.5 & 6.2 & 1.0 & 21.0 \\
Nov 08 & 6.4 & 6.5 & 13.6 & 0.3 & 5.3 & 10.8 \\
Apr 09 & 0.8 & 5.3 & 12.5 & 0.1 & 6.9 & 13.2 \\
Aug 09 & 5.7 & 6.6 & 5.7 & 1.8 & 3.5 & 31.6 \\
Dec 09 & 6.3 & 7.0 & 9.3 & 1.4 & 4.0 & 8.6 \\
Muncken & & & & & & \\
Apr 08 & 2.7 & 5.3 & 13.1 & 0 & 1.1 & 7.5 \\
Aug 08 & 16.6 & 5.9 & 7.2 & 4.9 & 0.7 & 9.3 \\
Nov 08 & 6.3 & 6.5 & 11.6 & 0.2 & 5.4 & 7.6 \\
Apr 09 & 1.7 & 5.2 & 13.6 & 0.2 & 4.0 & 5.2 \\
Aug 09 & 14.3 & 5.8 & 8.5 & 1.4 & 2.2 & 7.8 \\
Dec 09 & 4.6 & 5.5 & 11.5 & 0.1 & 4.3 & 8.6 \\
\hline
\end{tabular}

in April 2009 when the highest nitrification rate of the entire sampling period was observed (689.1 $\mu \mathrm{mol} \mathrm{N}$ $\mathrm{m}^{-2} \mathrm{~d}^{-1}$; Fig. 1). Although ${ }^{15} \mathrm{NO}_{3}{ }^{-}$was not measured in April 2009 (Muncken only) or December 2009 (both stations), assessment of $N_{\mathrm{w}}$ was possible from the total $\mathrm{NO}_{3}{ }^{-}$fluxes because, in April 2009, $\mathrm{NO}_{3}{ }^{-}$was effluxing in Muncken from all ${ }^{15} \mathrm{NH}_{4}{ }^{+}$concentrations indicating

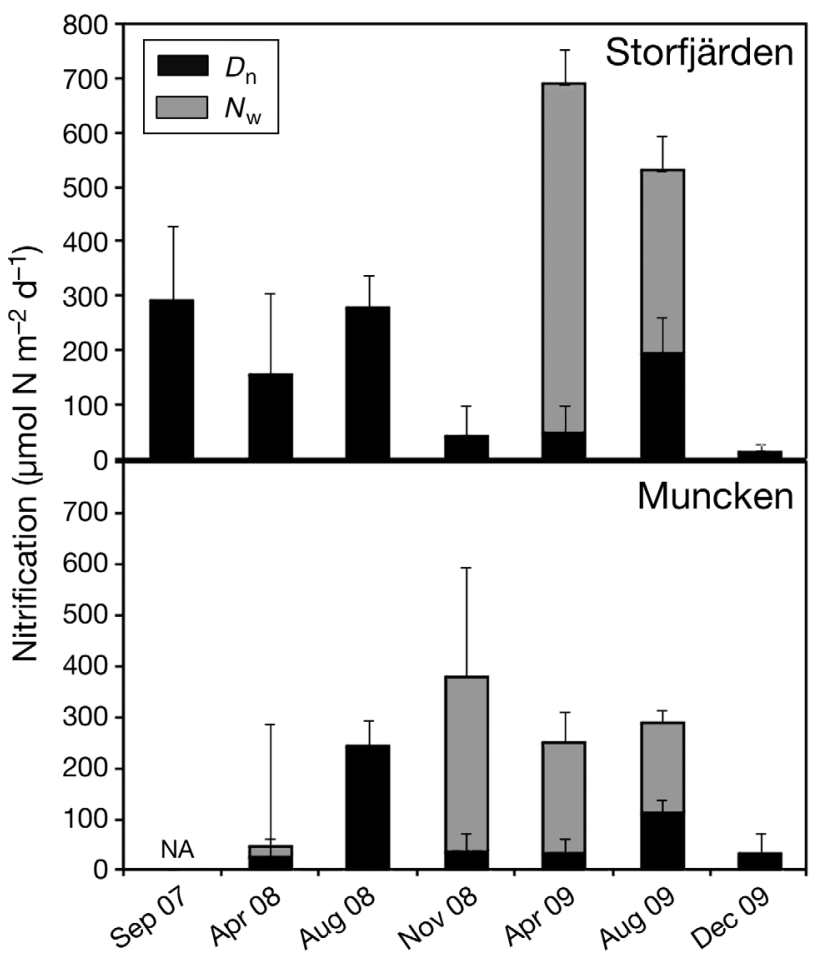

Fig. 1. Total nitrification rates and $\mathrm{SE}$, comprising nitrification coupled to denitrification ( $D_{\text {ni }}$ isotope-pairing technique) and nitrification producing $\mathrm{NO}_{3}{ }^{-}$to the water column $\left(\mathrm{N}_{\mathrm{wi}}{ }^{15} \mathrm{NH}_{4}{ }^{+}\right.$ oxidation). NA = data not available 


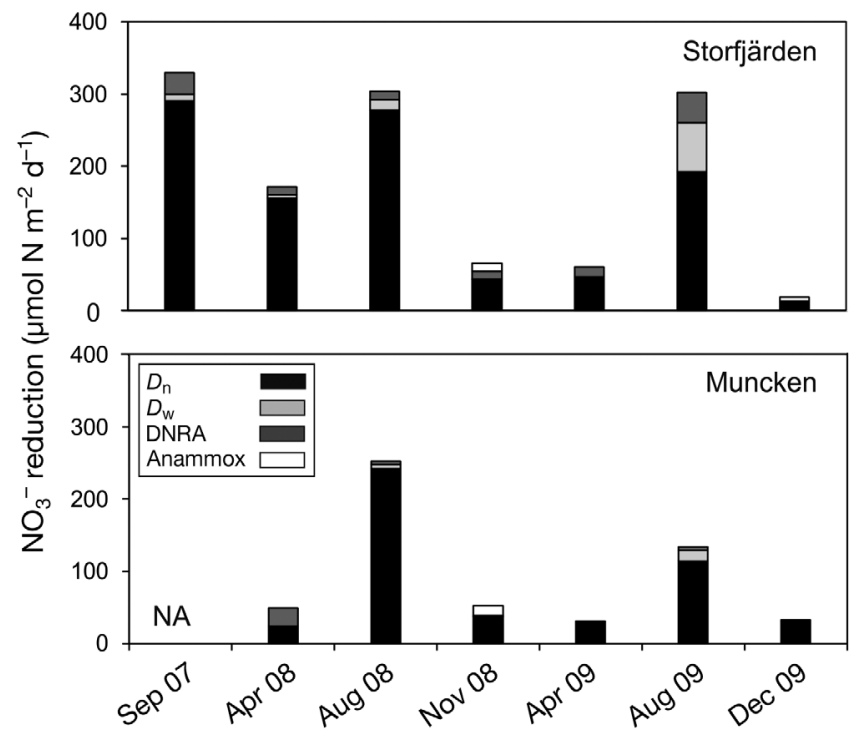

Fig. 2. $\mathrm{NO}_{3}{ }^{-}$-reduction pathways comprising coupled nitrification-denitrification $\left(D_{\mathrm{n}}\right)$, denitrification based on $\mathrm{NO}_{3}{ }^{-}$in the bottom water $\left(D_{\mathrm{w}}\right)$, dissimilatory nitrate reduction to ammonia (DNRA), and anammox. NA = data not available. DNRA data are not available for April 2009 in Muncken, and for December 2009 at both stations, and $D_{\mathrm{w}}$ is not available for April 2008 in Muncken and for April 2009 at both stations

nitrification of the added ${ }^{15} \mathrm{NH}_{4}{ }^{+}$. In December 2009, $\mathrm{NO}_{3}{ }^{-}$was influxing to the sediment in all ${ }^{15} \mathrm{NH}_{4}{ }^{+}$concentrations indicating that all $\mathrm{NO}_{3}{ }^{-}$produced by nitrification was consumed by $\mathrm{NO}_{3}^{-}$reduction. Consequently no ${ }^{15} \mathrm{NO}_{3}{ }^{-}$efflux was assumed (Figs. 1 \& 3). The denitrification rates were typically higher at Storfjärden than at Muncken, and denitrification was, with the exception of August 2009 in Storfjärden, tightly coupled with nitrification, nitrification providing more than $95 \%$ of the $\mathrm{NO}_{3}{ }^{-}$for the process (Fig. 2). Anammox was detected in November 2008 at both sampling stations, and in December 2009 at Storfjärden. In November 2008, anammox totalled 18\% (Storfjärden) and $26 \%$ (Muncken) of the $\mathrm{N}_{2}$ production and in December $200927 \%$ of the $\mathrm{N}_{2}$ production. At the times when anammox was detected, the total $\mathrm{N}_{2}$ production was low, and consequently the anammox rates were low (Fig. 2). DNRA was always detected when measured and, with the exception of April 2008 in Muncken, comprised 5 to $20 \%$ of the total $\mathrm{NO}_{3}{ }^{-}$reduction (Fig. 2). Although the DNRA comprised nearly half of the total $\mathrm{NO}_{3}{ }^{-}$reduction in April 2008 in Muncken, the overall nitrate-reduction rates were low, hence the DNRA rates were not high.

Production of ${ }^{15} \mathrm{~N}_{2}$ from ${ }^{15} \mathrm{NH}_{4}{ }^{+}$oxidation samples was typically equal to, or higher than, the $D_{\mathrm{n}}$ values measured from the denitrification samples. In April 2008 and December 2009 at Storfjärden, and in November 2008 and August 2009 in Muncken, the ${ }^{15} \mathrm{~N}_{2}$ production from ${ }^{15} \mathrm{NH}_{4}{ }^{+}$oxidation samples increased significantly linearly with ${ }^{15} \mathrm{NH}_{4}{ }^{+}$availability, indicating $\mathrm{NH}_{4}{ }^{+}$limitation of the first step of the coupled nitrification-denitrification pathway. A similar trend was also observed in both April samplings in Muncken, but the increase was not significantly linear (Fig. 3). The only sampling time when $D_{\mathrm{n}}$ measured with the IPT was significantly higher than the ${ }^{15} \mathrm{~N}_{2}$ production from ${ }^{15} \mathrm{NH}_{4}{ }^{+}$oxidation samples was August 2008 at both stations (Fig. 3). At that time the ${ }^{15} \mathrm{~N}$ labeling of the $\mathrm{NH}_{4}{ }^{+}$ pool in the nitrification layer was probably not complete owing to high $\mathrm{NH}_{4}{ }^{+}$availability in the sediment, as indicated by the relatively high $\mathrm{NH}_{4}{ }^{+}$concentration in bottom water and the LOI\% value compared to other values observed in the area (Table 2). As a consequence, the ${ }^{15} \mathrm{NH}_{4}{ }^{+}$added was not the only substrate for nitrification, which reduced the ${ }^{15} \mathrm{NO}_{3}{ }^{-}$and subsequent ${ }^{15} \mathrm{~N}_{2}$ production from ${ }^{15} \mathrm{NH}_{4}{ }^{+}$oxidation samples. $N_{\mathrm{w}}$ occurred more commonly in Muncken than in Storfjärden, and when $N_{\mathrm{w}}$ occurred in Storfjärden, the production of ${ }^{15} \mathrm{NO}_{3}{ }^{-}$did not increase with increasing ${ }^{15} \mathrm{NH}_{4}{ }^{+}$availability, whereas at Muncken, the production of ${ }^{15} \mathrm{NO}_{3}{ }^{-}$increased linearly with ${ }^{15} \mathrm{NH}_{4}{ }^{+}$availability in April 2008, November 2008 and April 2009. In August 2009, the increase was almost significantly linear ( $p=0.058$; Fig. 3).

In Storfjärden, there was a significant positive correlation between total denitrification and LOI\% $\left(\mathrm{r}_{\mathrm{S}}=\right.$ 0.893), bottom water $\mathrm{NH}_{4}{ }^{+}$concentration and total denitrification $\left(\mathrm{r}_{\mathrm{S}}=0.786\right)$, and temperature and $D_{\mathrm{n}}\left(\mathrm{r}_{\mathrm{S}}=\right.$ 0.829 ) - indicating that denitrification was stimulated when the sediment organic content and water temperatures increased. In Muncken, neither LOI\% nor temperature correlated with denitrification. There was a negative correlation in Storfjärden between anammox and denitrification $\left(\mathrm{r}_{\mathrm{S}}=-0.757\right)$ and anammox and LOI\% $\left(\mathrm{r}_{\mathrm{S}}=-0.757\right)$, suggesting that anammox was inhibited when denitrification rates and sediment organic content were high. Also, a significant negative correlation $\left(\mathrm{r}_{\mathrm{S}}=-0.829\right)$ was found between $\mathrm{O}_{2}$ concentration and DNRA rates in Storfjärden.

\section{DISCUSSION}

The highest nitrification potentials always occurred in April and late autumn (Fig. 3) when the primary production rates are lower than in August. This is in line with several previous studies that report high nitrification rates during low primary production (Focht \& Verstraete 1977, Kemp et al. 1990, Caffrey et al. 2007). The clearest reasons for the high nitrification potential are low sedimentation rates causing low decomposition and subsequent low $\mathrm{O}_{2}$ consumption rates, which in turn increase $\mathrm{O}_{2}$ availability for nitrification. However, 


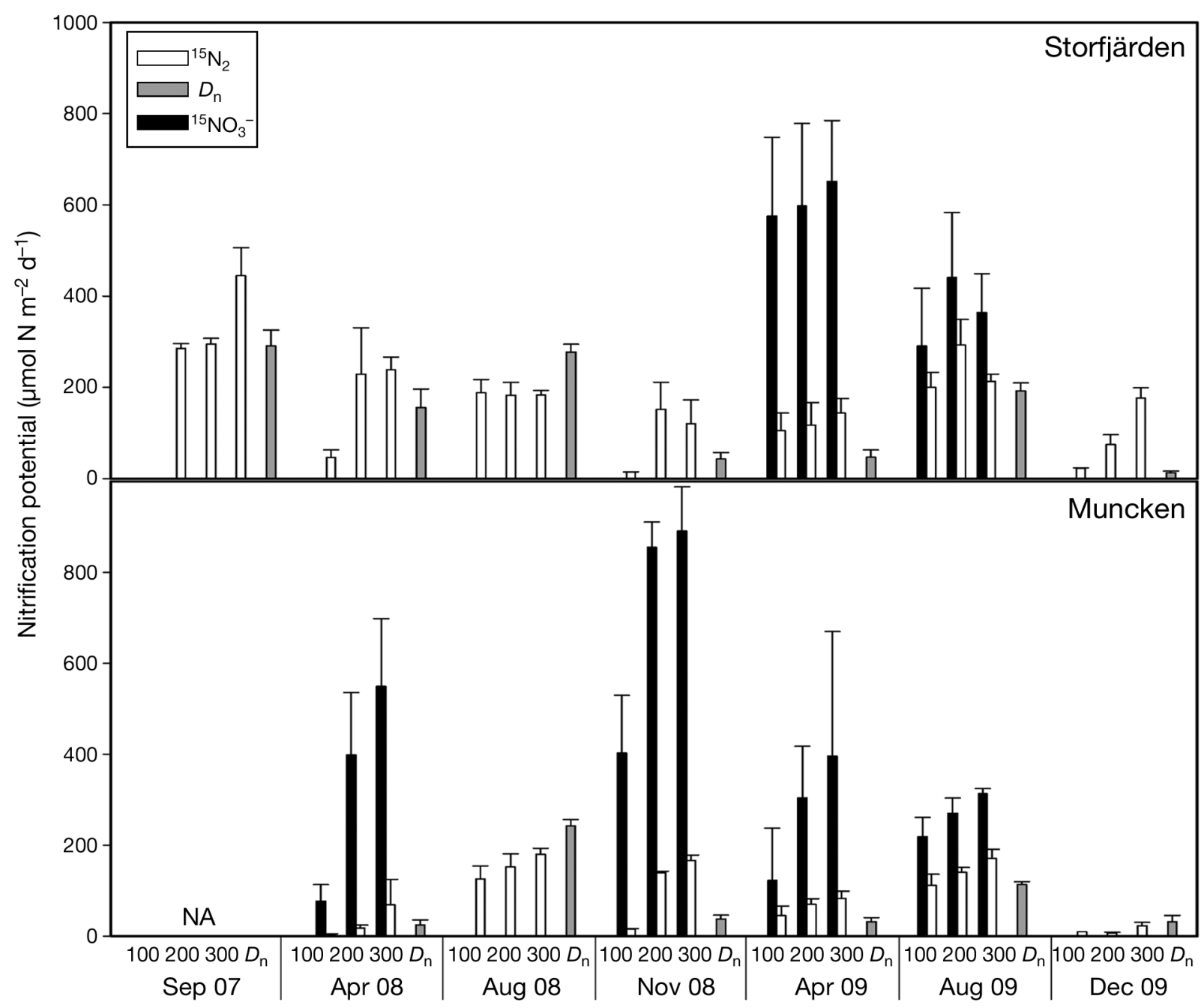

Fig. 3. Average and SE of nitrification potential shown as ${ }^{15} \mathrm{NO}_{3}{ }^{-}$and ${ }^{15} \mathrm{~N}_{2}$ productions from 3 different ${ }^{15} \mathrm{NH}_{4}{ }^{+}$concentrations $(100,200,300 \mu \mathrm{M})$ and coupled nitrification-denitrification $\left(D_{\mathrm{n}}\right)$ under in situ conditions (isotope-pairing technique). NA = data not available

the $\mathrm{NH}_{4}{ }^{+}$availability was low, and this limited nitrification. The nitrification rates measured under in situ conditions were highest, with the exception of Storfjärden in April 2009, during summer (Fig. 1). The high estimates of summer in situ nitrification rates were probably a result of high $\mathrm{NH}_{4}{ }^{+}$availability due to enhanced mineralization rates caused by the higher organic content of the sediment (Table 2). The limiting factor for nitrification must have been low $\mathrm{O}_{2}$ availability because heterotrophic bacteria, which are abundant when the organic content is high, have higher affinities for $\mathrm{O}_{2}$ than do nitrifiers (Verhagen \& Laanbroek 1991, Caffrey et al. 1993, Sloth et al. 1995, Strauss \& Lamberti 2000, Starry et al. 2005).

There was a significant positive correlation between LOI\% and denitrification rates, and LOI\% and denitri- fication potential in Storfjärden. The most obvious reason for the correlation between LOI\% and denitrification in Storfjärden is that denitrifying bacteria are heterotrophic (Payne 1973) and depend on organic carbon as their energy source. Also, when organic carbon availability was high, the estimated in situ nitrification rates were high, which provided $\mathrm{NO}_{3}{ }^{-}$for denitrification (Figs. 1 \& 2). The results agree with several previous studies that report high denitrification rates in sediment with an elevated organic content (Tuominen et al. 1998, Barnes \& Owens 1999, Dong et al 2000, Hietanen \& Kuparinen 2008). Muncken is a transportation area, where organic matter never accumulates, causing low variation in LOI\% values ( $4 \%$ ), and as a consequence, LOI\% and denitrification did not correlate. 
Denitrification was more frequently limited by the availability of $\mathrm{NO}_{3}{ }^{-}$in Storjärden than was the case in Muncken. When ${ }^{15} \mathrm{NO}_{3}{ }^{-}$was produced in the nitrification samples at Storfjärden, it was, with the exception of April and August 2009, immediately taken up by denitrification and, as a result, no ${ }^{15} \mathrm{NO}_{3}{ }^{-}$diffused into the water column (Fig. 3). At Muncken, denitrification was more saturated by the availability of $\mathrm{NO}_{3}{ }^{-}$; this was indicated by the fact that ${ }^{15} \mathrm{NO}_{3}{ }^{-}$from the nitrification samples diffused frequently into the bottom water rather than being reduced by denitrification (Fig. 3). Instead of $\mathrm{NO}_{3}{ }^{-}$limitation, denitrification was probably limited by carbon availability, because less carbon was available in Muncken than in Storfjärden (Table 2).

The nitrification potentials at Storfjärden were higher in 2009 than in 2008 (Fig. 3). One factor causing interannual variation in the nitrogen processes was a lack of ice cover in the winter of 2008 due to an exceptionally warm winter; this possibly caused the earlier development and sedimentation of a spring bloom, increasing the organic content of the sediment and possibly favoring heterotrophic bacteria over nitrifying bacteria in April 2008. In December 2009, the day before sampling, Storfjärden experienced a minor upwelling event which may have influenced nitrification. Sudden increases in salinity can cause an efflux of $\mathrm{NH}_{4}{ }^{+}$from the sediment-due to ion pairing of $\mathrm{NH}_{4}{ }^{+}$with saltwater anions, and the blocking of ion-exchange sites by seawater cations (Gardner et al. 1991, Seitzinger et al. 1991) - which would increase the availability of $\mathrm{NH}_{4}{ }^{+}$to nitrifiers and stimulate nitrification.

There are no data available for direct comparison of nitrification rates in the Baltic Sea sediments and, overall, we found only a few nitrification measurements made with intact sediment cores quantifying both nitrification producing $\mathrm{NO}_{3}{ }^{-}$to the water column and nitrification coupled to denitrification. Of the studies that were, to some extent, comparable in terms of measurement technique, the nitrification rates measured at the Danish coasts were at least 10-fold higher (Henriksen et al. 1981, Sloth et al. 1992), and at the Island of Sylt, Germany (Jensen et al. 1996) and a Danish lake (Rysgaard et al. 1993) 2-fold higher than those measured here (Fig. 1). At Chesapeake Bay (USA), the rates were nearly 20-fold higher in spring, but decreased to zero during the summer months (Jenkins \& Kemp 1984). All in all, the nitrification rates in the coastal Gulf of Finland were low, compared with rates measured in more southerly locations.

Although the nitrification rates and nitrification potentials, particularly at Storfjärden, were higher in 2009 (Figs. 1 \& 3), the denitrification rates at both stations were slightly lower in 2009 than in 2008 (Fig. 2). The explanation for the lower rates in 2009 might be lower water temperature. The lack of ice cover in 2008 al- lowed earlier penetration of light to the surface water, and a faster warm-up of the water, stimulating all biological processes very early in the spring of that year. Also, in August 2009, the water column in Storfjärden had not yet mixed by the sampling time (unlike the situation in 2008), causing an almost $10^{\circ} \mathrm{C}$ difference in the bottom water temperatures (Table 2); this may have decreased the denitrification rates. This is also supported by the significant positive correlation between temperature and denitrification. Compared to the rates measured in Storfjärden in the period 2003 to 2004 (Hietanen \& Kuparinen 2008), denitrification was almost $50 \%$ lower. However, because the previous data had not been gathered using r-IPT in all seasons, they are directly comparable only for spring and summer rates. Still, even assuming that anammox would have contributed $10 \%$ to the $\mathrm{N}_{2}$ production during those seasons when r-IPT was not applied, the denitrification rates had decreased (Hietanen \& Kuparinen 2008). We found no apparent reason for the decreased rates from the long-term monitoring data (2002 to 2009; $\mathrm{O}_{2}$, temperature, salinity, chlorophyll a) of the area, but we discovered a high abundance of the invasive polychaete worm Marenzelleria spp. (Bick \& Burckhardt 2008) in the samples at all times. Marenzelleria spp. are recent invaders in the Gulf of Finland and were not present in such high numbers in the period 2003 to 2004, compared with the present study. These animals do not have a major impact on denitrification (Hietanen et al. 2007) but they tolerate low-oxygen conditions (Schiedek 1997, Hahlbeck et al.2000), and the increase in their abundance might be an indication that the sampling area has recently experienced hypoxia to an extent greater than that seen in the period 2003 to 2004 .

In general, the rates of denitrification in the coastal Gulf of Finland are low compared to more southerly locations. For example, the rates were 20-fold lower than in the Colne estuary, UK (Dong et al 2000, 2009), and approximately 100-fold lower than in the Rowley River estuary, USA (Tobias et al. 2003), Humber estuary, UK (Barnes \& Owens 1999) and Thames estuary, UK (Trimmer et al. 2000). However, in most of these sites the $\mathrm{NO}_{3}^{-}$concentrations were substantially higher, which may explain the large difference in the rates. When compared to sites in the same latitude, our rates were lower than the denitrification rates measured in the open Gulf of Finland sediments (Tuominen et al. 1998) and in the Archipelago Sea (Silvennoinen et al. 2007), but higher than in the eastern Gulf of Finland (Gran \& Pitkänen 1999) and in the Gulf of Bothnia (Stockenberg \& Johnstone 1997).

Anammox was previously reported in the sampling area in May and August 2003 (Hietanen \& Kuparinen 2008). In the present study, we tested for anammox at all sampling times, and it was detected only in late 
autumn when the total $\mathrm{N}_{2}$ production rates and the anammox rates were very low. Anammox rates negatively correlated with LOI\% and denitrification, hence the appearance of anammox may have been due to a decrease in the availability of organic carbon needed for denitrification, when anammox did not have to compete for $\mathrm{NO}_{3}{ }^{-}$with denitrifying bacteria (Thamdrup \& Dalsgaard 2002, Dalsgaard et al. 2005, Engström et al. 2005). The presence of anammox can also be explained by low water temperatures because anammox appears to be favored in colder environments (Rysgaard et al. 2004, Trimmer et al. 2005). Overall, the present study confirms the previous results by Hietanen \& Kuparinen (2008) that anammox has a minor role as a nitrogen-removing process in the coastal Gulf of Finland.

Direct measurements of coupled nitrification-DNRA are impossible with stable isotope-based methods because the substrate and the end product of the pathway are the same. DNRA is typically measured by adding ${ }^{15} \mathrm{NO}_{3}{ }^{-}$and monitoring the production of ${ }^{15} \mathrm{NH}_{4}{ }^{+}$, as was also done in the present study. However, due to the addition of ${ }^{15} \mathrm{NO}_{3}{ }^{-}$, the substrate availability for DNRA increased and the ${ }^{15} \mathrm{NH}_{4}{ }^{+}$production is only a measure of DNRA potential. Scaling the DNRA rate to the ambient $\mathrm{NO}_{3}^{-}$levels is challenging. The actual ${ }^{15 / 14} \mathrm{~N}$ ratio of the $\mathrm{NO}_{3}{ }^{-}$consumed by DNRA is difficult to estimate because the ${ }^{15} \mathrm{~N}$ label of the $\mathrm{NO}_{3}{ }^{-}$pool is constantly diluted by ${ }^{14} \mathrm{NO}_{3}{ }^{-}$ produced by nitrification. In the calculations presented by Christensen et al. (2000), the ${ }^{15 / 14} \mathrm{~N}$ ratio of the $\mathrm{NO}_{3}{ }^{-}$consumed was proposed to be similar to the ${ }^{15 / 14} \mathrm{~N}$ ratio of the $\mathrm{N}_{2}$ produced by denitrification, because DNRA and denitrification occur at the same anoxic sediment depth right below the oxic layer. To estimate DNRA rates accurately with this technique, the ${ }^{15} \mathrm{NH}_{4}{ }^{+}$production should increase in parallel with the ${ }^{15} \mathrm{~N}$ content of the $\mathrm{N}_{2}$ produced by denitrification, which was not the case in the present study. Alternatively, Dong et al. (2009) proposed that the ${ }^{15 / 14} \mathrm{~N}$ ratio of the $\mathrm{NO}_{3}{ }^{-}$consumed is simply the ratio of the ambient ${ }^{14} \mathrm{NO}_{3}{ }^{-}$and the added ${ }^{15} \mathrm{NO}_{3}{ }^{-}$, and the isotopes are consumed by DNRA in the same ratio as they are available in the water phase. Because the DNRA was not nitrate-limited, and the IPT calculation formulas could not be applied in all seasons due to lack of $\mathrm{NO}_{3}{ }^{-}$limitation in denitrification, we used the calculation scheme of Dong et al. (2009). The DNRA rates measured were comparable to those in 2 lowland lakes (Nizzoli et al. 2010) and a wetland (Scott et al. 2008), but were at least 10-fold lower in comparison to marine sediments (Jørgensen 1989, Rysgaard et al. 1996). High rates of DNRA have been reported from sediments that have high concentrations of sulfide and/or a high organic content, caus- ing a low redox potential (Burgin \& Hamilton 2007), and a negative correlation between $\mathrm{O}_{2}$ concentration and DNRA rates was also found in the present study. The low rates of DNRA measured in this study were probably a result of a permanently oxidized top layer of sediment, creating an environment with low concentrations of sulfide and a high redox potential at the sediment layer where $\mathrm{NO}_{3}{ }^{-}$is available.

The results shown here emphasize the limited capacity of the coastal Gulf of Finland sediments to purify the nitrogen load from the land. It has been estimated that the total nitrogen load from the drainage basin to the sampling area is 40 to 50 tonnes of nitrogen in each month (Malve et al. 2000). By assuming that the denitrification rates in the entire river outflow area $\left(22.5 \mathrm{~km}^{2}\right)$ are equal to denitrification rates measured in Muncken, denitrification removes $\sim 2 \%$ of the nitrogen load. If the denitrification rates in the river outflow area are approximately the same as those in Storfjärden, denitrification removes $2.8 \%$ of the nitrogen load. Depositional areas, similar to Storfjärden, have been estimated to cover only 25 to $35 \%$ of the Gulf of Finland $(\mathrm{H}$. Kankaanpää \& H. Vallius pers. comm.); hence the former estimate might be more accurate. If the rates are expanded to the entire Gulf of Finland $\left(29600 \mathrm{~km}^{2}\right)-$ assuming the $25 \%$ areal coverage of the depositional areas and $75 \%$ coverage of transportation areas denitrification and anammox removed $\sim 16 \mathrm{kt} \mathrm{N} \mathrm{yr}^{-1}$, which is substantially less than the 39 to $45 \mathrm{kt}$ estimates of Tuominen et al. (1998) and Hietanen \& Kuparinen (2008). Moreover, the $16 \mathrm{kt} \mathrm{N} \mathrm{yr}^{-1}$ is probably an overestimate because, in the period 2008 to 2009, the Gulf of Finland had vast anoxic areas. The bottom-water $\mathrm{O}_{2}$ conditions in the Gulf of Finland are highly regulated by salt water inflows from the Baltic Sea main basins that strengthen the stagnation of the water column, which, in turn, prevents mixing of the water column. In the period 2008 to 2009 the water column stagnation was strong, which may also explain the decreased denitrification rates.

It is noteworthy that when the loading from land is highest, during spring, the natural capacity of the sediments to purify the nitrogen load is at its lowest. The increasing winter rains predicted for the northern Baltic Sea, due to climate change (HELCOM 2007), can increase the annual nitrogen load substantially. High nitrogen loading, particularly during winter, creates more intense spring blooms, which, in turn, can increase the area of anoxic seafloor because most of the sedimenting material in the Gulf of Finland originates from the spring bloom (Tallberg \& Heiskanen 1998, Conley et al. 2009). Therefore, the control of nitrogen loading from the entire drainage basin is essential in the battle against eutrophication. 


\section{CONCLUSION}

Nitrification and denitrification in the coastal Gulf of Finland follows a seasonal pattern, with the highest rates occurring during late summer and low rates during late fall and spring. When the denitrification rates were at their highest, denitrification was limited by the nitrification rate but the $\mathrm{NH}_{4}{ }^{+}$availability did not limit nitrification. In the accumulation basin, nitrification was occasionally limited by $\mathrm{NH}_{4}{ }^{+}$availability, and the nitrification potentials were typically lower than in the transportation area. When nitrification was stimulated by adding excess $\mathrm{NH}_{4}{ }^{+}$to the bottom water, denitrification generally reduced all of the $\mathrm{NO}_{3}{ }^{-}$that was produced to $\mathrm{N}_{2}$. In the transportation area, nitrification was frequently limited by $\mathrm{NH}_{4}{ }^{+}$availability, and when nitrification was stimulated by adding $\mathrm{NH}_{4}{ }^{+}$, the $\mathrm{NO}_{3}{ }^{-}$ produced could not be utilized by denitrification, causing $\mathrm{NO}_{3}{ }^{-}$to efflux to the bottom water. The magnitudes of the alternative $\mathrm{NO}_{3}{ }^{-}$reduction pathways, anammox and DNRA, in the area were small. The rates of DNRA remained low in all seasons, and anammox appeared only in late autumn when the nitrate-reduction rates altogether were low. The denitrification rates in the Gulf of Finland have decreased from the values measured in the early 2000s; this suggests that sediment denitrification might be a less important sink for fixed nitrogen than was previously assumed. It is also noteworthy that the natural capacity of the coastal sediments to mitigate the nitrogen load was at its lowest during spring, when the flux of nitrogen from the drainage basin is highest.

Acknowledgements. We thank A. Vetterli, H. Holmroos and J. Horppila at the Department of Environmental Sciences, University of Helsinki, Finland, for helpful comments during the writing process, and K. Kähkönen at the Department of Environmental Sciences (Lahti Campus), University of Helsinki, Finland for help during the sample collection. We acknowledge grants from the Onni Talas Foundation, Academy of Finland (116477), BONUS+ project Assessment and Modelling of Baltic Ecosystem Response (AMBER) and Maa-ja vesitekniikan tuki ry.

\section{LITERATURE CITED}

Barnes J, Owens NJP (1999) Denitrification and nitrous oxide concentrations in the Humber estuary, UK, and adjacent coastal zones. Mar Pollut Bull 37:247-260

Bick A, Burckhardt R (2008) Erstnachweis von Marenzelleria viridis (Polychaeta, Spionidae) für den Ostseeraum, mit einem Bestimmungsschlüssel der Spioniden der Ostsee. Mitt Zool Mus Berl 65:237-247

Burgin AJ, Hamilton SK (2007) Have we overemphasized the role of denitrification in aquatic ecosystems? A review of nitrate removal pathways. Front Ecol Environ 5: 89-96
Caffrey J, Sloth N, Kaspar H, Balckburn T (1993) Effect of organic loading on nitrification and denitrification in marine sediment microcosm. FEMS Microbiol Ecol 12: $159-167$

Caffrey J, Bano N, Kalanetra K, Hollibaugh J (2007) Ammonia oxidation and ammonia-oxidizing bacteria and archaea from estuaries with different histories of hypoxia. ISME J 1:660-662

> Christensen PB, Rysgaard S, Sloth NP, Dalsgaard T, Schwærter S (2000) Sediment mineralization, nutrient fluxes, denitrification and dissimilatory nitrate reduction to ammonium in an estuarine fjord with sea cage trout farms. Aquat Microb Ecol 21:73-84

Conley DJ, Paerl HW, Howarth RW, Boesch DF and others (2009) Controlling eutrophication: nitrogen and phosphorus. Science 323:1014-1015

Dalsgaard T, Thamdrup B, Canfield DE (2005) Anaerobic ammonium oxidation (anammox) in the marine environment. Res Microbiol 156:457-464

> Dong LF, Thornton DCO, Nedwell DB, Underwood GJC (2000) Denitrification in sediments of the River Colne estuary, England. Mar Ecol Prog Ser 203:109-122

> Dong LF, Smith CJ, Papaspyrou S, Stott A, Osborn AM, David B, Nedwell DB (2009) Changes in benthic denitrification, nitrate ammonification, and anammox process rates and nitrate and nitrite reductase gene abundances along an estuarine nutrient gradient (the Colne estuary, United Kingdom). Appl Environ Microbiol 75:3171-3179

> Engström P, Dalsgaard T, Hulth S, Aller RC (2005) Anaerobic ammonium oxidation by nitrite (anammox): implications for $\mathrm{N}_{2}$ production in coastal marine sediments. Geochim Cosmochim Acta 69:2057-2065

Focht DD, Verstraete W (1977) Biochemical ecology of nitrification and denitrification. Adv Microb Ecol 1:135-214

Gardner WS, Seitzinger SP, Malczyk JM (1991) The effects of sea salts on the forms of nitrogen released from estuarine and freshwater sediments: Does ion pairing affect ammonium flux? Estuar Coast 14:157-166

Gran V, Pitkänen H (1999) Denitrification in estuarine sediments in the eastern Gulf of Finland, Baltic Sea. Hydrobiologia 393:107-115

Hahlbeck E, Arndt C, Schiedek D (2000) Sulphide detoxification in Hediste diversicolor and Marenzelleria viridis, two dominant polychaete worms within the shallow coastal waters of the southern Baltic Sea. Comp Biochem Physiol Part B Biochem Mol Biol 125:457-471

HELCOM (Helsinki Commission) (2007) Climate change in the Baltic Sea area. Baltic Sea Environment Proceedings No. 111

HELCOM (Helsinki Commission) (2009) Eutrophication in the Baltic Sea: an integrated thematic assessment of the effects of nutrient enrichment in the Baltic Sea region. Baltic Sea Environment Proceedings No. 115

> Henriksen K, Hansen IJ, Blackburn TH (1981) Rates of nitrification, distribution of nitrifying bacteria, and nitrate fluxes in different types of sediment from Danish waters. Mar Biol 61:299-304

Hietanen S, Kuparinen J (2008) Seasonal and short-term variation in denitrification and anammox at coastal station in the Gulf of Finland, Baltic Sea. Hydrobiologia 596:67-77

Hietanen S, Lainen AO, Lukkari K (2007) The complex effects of the invasive polychaetes Marenzelleria spp. on benthic nutrient dynamics. J Exp Mar Biol Ecol 352:89-102

Jenkins M, Kemp W (1984) The coupling of nitrification and denitrification in two estuarine sediments. Limnol Oceanogr 29:609-619

Jensen K, Revsbech N, Nielsen N (1993) Microscale distribu- 
tion of nitrification activity in sediment determined with a shielded microsensor for nitrate. Appl Environ Microbiol 59:3287-3296

> Jensen K, Sloth N, Risgaard-Petersen N, Rysgaard S, Revsbech N (1994) Estimation of nitrification and denitrification from microprofiles of oxygen and nitrate in model sediment systems. Appl Environ Microbiol 60:2094-2100

Jensen KM, Jensen MH, Kristensen E (1996) Nitrification and denitrification in Wadden Sea sediments (Königshafen, Island of Sylt, Germany) as measured by nitrogen isotope pairing and isotope dilution. Aquat Microb Ecol 11: 181-191

> Jørgensen KS (1989) Annual pattern of denitrification and nitrate ammonification in estuarine sediment. Appl Environ Microbiol 55:1841-1847

Karlsson K, Hulth S, Ringdahl K, Rosenberg R (2005) Experimental recolonisation of Baltic Sea reduced sediments: survival of benthic macrofauna and effects on nutrient cycling. Mar Ecol Prog Ser 294:35-49

Kemp W, Sampou P, Caffrey J, Mayer M, Henriksen K, Boynton W (1990) Ammonium recycling versus denitrification in Chesapeake Bay sediments. Limnol Oceanogr 35: $1545-1563$

Könneke M, Bernhart AE, de la Torre JR, Walker CB, Waterbury JB, Stahl DA (2005) Isolation of an autotrophic ammonia-oxidizing marine archaeon. Nature 437:543-546

Malve O, Virtanen M, Villa L, Karonen M and others (2000) Pohjanpitäjänlahden syvänteessä vuosina 1995 ja 1996 toteutettu hapetuskokeilu. (Oxidation experiment in deep waters of Pojo Bay in 1995-1996.) Suomen ympäristo Series No 377.

Nielsen LP (1992) Denitrification in sediment determined from nitrogen isotope pairing. FEMS Microbiol Ecol 86: $357-362$

Niemi $\AA$ (1975) Ecology of phytoplankton in the Tvärminne area SW coast of Finland. II. Primary production and environmental conditions in the archipelago zone and sea zone. Acta Bot Fenn 105:1-73

Nizzoli D, Carraro E, Nigro V, Viaroli P (2010) Effect of organic enrichment and thermal regime on denitrification and dissimilatory nitrate reduction to ammonium (DNRA) in hypolimnetic sediments of two lowland lakes. Water Res 44:2715-2724

Payne WJ (1973) Reduction of nitrogenous oxides by microorganisms. Bacteriol Rev 37:409-452

> Pitkänen H, Tamminen T (1995) Nitrogen and phosphorus as production limiting factors in the estuarine waters of the eastern Gulf of Finland. Mar Ecol Prog Ser 129: 283-294

Risgaard-Petersen N, Rysgaard S, Revsbech NP (1995) Combined microdiffusion-hypobromite oxidation method for determining nitrogen-15 isotope in ammonium. Soil Sci Soc Am J 59:1077-1080

Risgaard-Petersen N, Nielsen LP, Rysgaard S, Dalsgaard T, Meyer RL (2003) Application of the isotope pairing technique in sediments where anammox and denitrification coexist. Limnol Oceanogr Methods 1:63-73

Risgaard-Petersen N, Nielsen LP, Rysgaard S, Dalsgaard T, Meyer RL (2004) Erratum: Application of the isotope pairing technique in sediments where anammox and denitrification coexist. Limnol Oceanogr Methods 2:315

Rysgaard S, Risgaard-Petersen N, Nielsen LP, Revsbech NP (1993) Nitrification and denitrification in lake and estuarine sediments measured by the ${ }^{15} \mathrm{~N}$ dilution technique and isotope pairing. Appl Environ Microbiol 59:2093-2098

> Rysgaard S, Risgaard-Petersen N, Sloth NP (1996) Nitrification, denitrification, and nitrate ammonification in sediments of two coastal lagoons in Southern France. Hydrobiologia 329:133-141

Rysgaard S, Glud RN, Risgaard-Petersen N, Dalsgaard T (2004) Denitrification and anammox activity in Arctic marine sediments. Limnol Oceanogr 49:1493-1502

Schiedek D (1997) Marenzelleria cf. viridis (Polychaeta: Spionidae) - ecophysiological adaptions to a life in the coastal waters of the Baltic Sea. Aquat Ecol 31:199-210

Scott J, McCarthy M, Gardner W, Doyle R (2008) Denitrification, dissimilatory nitrate reduction to ammonium, and nitrogen fixation along a nitrate concentration gradient in a created freshwater wetland. Biogeochemistry 87:99-111

Seitzinger SP, Gardner WS, Spratt AK (1991) The effect of salinity on ammonium sorption in aquatic sediments: Implications for benthic nutrient recycling. Estuaries Coasts 14:167-174

Seitzinger S, Harrison JA, Böhlke JK, Bouwman AF and others (2006) Denitrification across landscapes and waterscapes: a synthesis. Ecol Soc Am 16:2064-2090

Sigman DM, Altabet MA, Michener R, McCorcle DC, Fry B, Holmes RM (1997) Natural abundance-level measurement of nitrogen isotopic composition of oceanic nitrate: an adaptation of the ammonia diffusion method. Mar Chem $57: 227-242$

> Silvennoinen H, Hietanen S, Liikanen A, Stange CF, Russow R, Kuparinen J, Martikainen PJ (2007) Denitrification in the river estuaries of the Northern Baltic Sea. Ambio 36: $134-140$

> Sloth NP, Nielsen LP, Blackburn TH (1992) Nitrification in sediment cores measured with acetylene inhibition. Limnol Oceanogr 37:1108-1112

Sloth NP, Blackburn H, Hansen LS, Risgaard-Petersen N, Lomstein BA (1995) Nitrogen cycling in sediments with different organic loading. Mar Ecol Prog Ser 116:163-170

Solorzano L (1969) Determination of ammonia in natural water by the phenolhypochlorite method. Limnol Oceanogr 14:799-801

> Stange CF, Spott O, Apelt B, Russow RWB (2007) Automated rapid online determination of ${ }^{15} \mathrm{~N}$ abundance and concentration of ammonium, nitrite, or nitrate in aqueous samples by the SPINMAS technique. Isotopes Environ Health Stud 43:227-236

Starry O, Valett M, Schreiber M (2005) Nitrification rates in headwater stream: influences of seasonal variation in $\mathrm{C}$ and N supply. J N Am Benthol Soc 24:753-761

Steingruber SM, Friedrich J, Gächter R, Wehrli B (2001) Measurement of denitrification in sediments with the ${ }^{15} \mathrm{~N}$ isotope pairing technique. Appl Environ Microbiol 67: 3771-3778

Stockenberg A, Johnstone RW (1997) Benthic denitrification in the Gulf of Bothnia. Estuar Coast Shelf Sci 45:835-843

Strauss E, Lamberti G (2000) Regulation of nitrification in aquatic sediments by organic carbon. Limnol Oceanogr 45:1854-1859

Tallberg P, Heiskanen A (1998) Species-specific phytoplankton sedimentation in relation to primary production along an inshore-offshore gradient in the Baltic Sea. J Plankton Res 20:2053-2070

> Thamdrup B, Dalsgaard T (2002) Production of $\mathrm{N}_{2}$ through anaerobic ammonium oxidation coupled to nitrate reduction in marine sediments. Appl Environ Microbiol 68: 1312-1318

> Tiedje JM, Sexstone AJ, Myrold DD, Robinson JA (1982) Denitrification: ecological niches, competition and survival. Antonie van Leeuwenhoek 48:569-583

> Tobias C, Giblin A, McClelland J, Tucker J, Peterson B (2003) Sediment DIN fluxes and preferential recycling of benthic 
microalgal nitrogen in a shallow macrotidal estuary. Mar Ecol Prog Ser 257:25-36

Trimmer M, Nedwell DB, Sivyer DB, Malcolm SJ (2000) Seasonal benthic organic matter mineralisation measured by oxygen uptake and denitrification along a transect of the inner and outer River Thames estuary, UK. Mar Ecol Prog Ser 197:103-119

Trimmer M, Nicholls JC, Morley N, Davies CA, Aldridge J (2005) Biphasic behavior of anammox regulated by nitrite and nitrate in an estuarine sediment. Appl Environ Microbiol 71:1923-1930

Editorial responsibility: Patricia Glibert, Cambridge, Maryland, USA
Tuominen L, Heinnen A, Kuparinen J, Nielsen N (1998) Spatial and temporal variability of denitrification in the sediments of northern Baltic Proper. Mar Ecol Prog Ser 172:13-24

Verhagen FJM, Laanbroek HJ (1991) Competition for ammonium between nitrifying and heterotrophic bacteria in dual energy-limited chemostats. Appl Environ Microbiol 57:3255-3263

Voss M, Emeis K-C, Hille S, Neumann T, Dippner JW (2005) Nitrogen cycle of the Baltic Sea from an isotopic perspective. Global Biogeochem Cycles 19:GB 3001 doi:10.1029/ 2004GB002338

Submitted: May 12, 2010; Accepted: January 10, 2011 Proofs received from author(s): April 5, 2011 